\title{
An Overview on Bioequivalence: Regulatory Consideration for Generic Drug Products
}

Asif M. Tamboli*, Pavan Todkar, Priti Zope and F.J. Sayyad

Government College of pharmacy Vidynagar Karad, Maharashatra-415110,India

\begin{abstract}
Generic pharmaceutical products need to confirm to the same standards of quality, efficacy and safety as required of the originator's (innovator) product. Specifically, the Generic product should be therapeutically equivalent and interchangeable with the reference product. Testing the bioequivalence between a test product pharmaceutically equivalent or a pharmaceutical alternative and a suitable reference product in a pharmacokinetic study with a limited number of subjects is one way of demonstrating therapeutic equivalence. Generic drug applications are termed "abbreviated" because they are generally not required to include preclinical and clinical data to establish safety and effectiveness. This paper provides the information about important aspect involved in bioequivalence and Regulatory requirement for Bioequivalence study.
\end{abstract}

Keywords: US FDA; EMEA; MCC;Body mass index;Confidence interval; AUC

Abbreviations: FDA: Food and Drug Administration; EMA: European medical agency; BA/BE: Bioavailability and Bioequivalence; MCC: Medicine control council; AUC: Area under Curve; ANDA: Abbreviated new drug application

\section{Introduction}

\section{Generic drug}

According to the U.S. Food and Drug Administration (FDA), generic drugs are identical or within an acceptable bioequivalent range to the brand name counterpart with respect to pharmacokinetic and pharmacodynamic properties. By extension, therefore, generics are considered (by the FDA) identical in dose, strength, route of administration, safety, efficacy, and intended use. The FDA's use of the word identical is very much a legal interpretation, and is not literal. In most cases, generic products are available once the patent protections afforded to the original developer have expired. When generic products become available, the market competition often leads to substantially lower prices for both the original brand name product and the generic forms.

\section{Hatch waxman act}

Using bioequivalence as the basis for approving generic copies of drug products was established by the "Drug Price Competition and Patent Term Restoration Act of 1984," also known as the Waxman-Hatch Act. Under Hatch-Waxman Act, one of the following four certifications has to be made while filing an ANDA: [Food and drug administration, center for drug evaluation and research (CDER)].

\begin{tabular}{|l|l|l|}
\hline Type & Patent Certification & ANDA Filing \\
\hline Paragraph I & The drug has not been patented. & $\begin{array}{l}\text { If a generic drug manufacturer certifies I \& II, then the FDA starts } \\
\text { processing the generic ANDA right away }\end{array}$ \\
\hline Paragraph II & The patent has already expired. & $\begin{array}{l}\text { If a generic drug manufacturer certifies 3, then the FDA starts processing } \\
\text { the ANDA, and gives approval when the patent expires }\end{array}$ \\
\hline Paragraph III & expiry of the patent & $\begin{array}{l}\text { ANDA filer notifies patent holder within } 20 \text { days } \\
- \text { Patent holder must sue for infringement within } 45 \text { days } \\
- \text { If the patent holder sues, FDA must withhold approval for } 30 \text { months } \\
\text { (one time only) } \\
\text { - If the patent holder does not sue, FDA may approve ANDA at any time } \\
- \text { If a court rules that the patent is not infringed or invalid, FDA may } \\
\text { proceed after decision. } \\
\text { - If first generic ANDA files will gets 180 days exclusivity (per product) }\end{array}$ \\
\hline
\end{tabular}

Important aspect involved in bioequivalence and Regulatory requirement

a) Standardisation of study: The test conditions should be standardised in order to minimise the variability of all factors involved except that of the products being tested. Bioequivalence study will be carried out in healthy volunteer unless drug carried safety issue it will carry out in patient(US FDA General consideration BA/BE, 2003).

*Corresponding author: Asif M. Tamboli, 538, Peth Bhag Gavali Galli, Sangli-416416 Maharashtra, India, Tel: +919028906245; +919960552578; E-mail: asiftamboli2008@ rediffmail.com, asiftamboli2008@gmail.com

Received August 16, 2010; Accepted September 06, 2010; Published September 06, 2010

Citation: Tamboli AM, Todkar P, Zope P, Sayyad FJ (2010) An Overview on Bioequivalence: Regulatory Consideration for Generic Drug Products. J Bioequiv Availab 2: 086-092. doi:10.4172/jbb.1000037

Copyright: @ 2010 Tamboli AM, et al. This is an open-access article distributed under the terms of the Creative Commons Attribution License, which permits unrestricted use, distribution, and reproduction in any medium, provided the original author and source are credited. 
Citation: Tamboli AM, Todkar P, Zope P, Sayyad FJ (2010) An Overview on Bioequivalence: Regulatory Consideration for Generic Drug Products. J Bioequiv Availab 2: 086-092. doi:10.4172/jbb.1000037

i) Demographic requirement:

\begin{tabular}{|c|c|c|c|}
\hline Regulatory Agency & Age (year) & BMI $\left(\mathrm{kg} / \mathrm{m}^{2}\right)$ & SEX \\
\hline U.S.A & 18 years of age or older & $18.5-24.9$ & Both sex \\
\hline Europe & 18 years of age or older & $18.5-30$ & Both sex \\
\hline Japan & Healthy adult volunteers & $18.5-25.0$ & ------- \\
\hline Canada & 18 to 55 older & $\begin{array}{c}\text { Height/weight ratio for healthy volunteer } \\
\text { subjects should be within } 15 \text { percent of the } \\
\text { normal range. }\end{array}$ & Both sex \\
\hline Australia & Between 18-55 & Accepted Normal BMI & Both sex \\
\hline Saudi Arabia & Between 18-50 & $\begin{array}{c}\text { Within } 15 \% \text { of ideal body weight, height and } \\
\text { body build. }\end{array}$ & $\begin{array}{l}\text { If females are included in the study, } \\
\text { the effects of gender differences and } \\
\text { menstrual cycle (if applicable) are } \\
\text { examined statistically. }\end{array}$ \\
\hline ASEAN & Between 18-55 & 18.5 and $25 \mathrm{~kg} / \mathrm{m}^{2}$ & Both sex \\
\hline South Korea & $19-55$ & --- & ---- \\
\hline Mexico & 18 and 55 & weight $10 \%$ from the ideal weight & $\begin{array}{l}\text { To avoid pharmacokinetic differences } \\
\text { between sexes is well documented; } \\
\text { volunteers of just one sex must be } \\
\text { included. }\end{array}$ \\
\hline China & $\begin{array}{c}18 \text { to } 40 \text { years of age generally, the same subjects } \\
\text { were not different from } 10 \text { years of age. }\end{array}$ & Standard weight range. & Both sex \\
\hline
\end{tabular}

ii) Diet and fluid requirement:

\begin{tabular}{|c|c|c|}
\hline Regulatory Agency & Diet & Fluid intake \\
\hline Europe and Australia & $\begin{array}{l}\text { i) No food is allowed for at least } 4 \text { hours post-dose. Meals taken after } \\
\text { dosing should be standardised in regard to composition and time of } \\
\text { Administration during an adequate period of time. (fasting study) } \\
\text { ii) In fed conditions, the timing of administration of the drug product in } \\
\text { relation to food intake is recommended to be according to the SmPC } \\
\text { of the originator product. If no specific recommendation is given in } \\
\text { the originator SmPC, it is recommended that subjects should start the } \\
\text { meal } 30 \text { minutes prior to administration of the drug product and eat } \\
\text { this meal Within } 30 \text { minutes. (fed study) } \\
\text { (Europe BA/B CPMP/EWP/QWP/1401/98 Rev. } 1 / \text { Corr *) }\end{array}$ & $\begin{array}{l}\text { i) Test and reference products should be administered with a } \\
\text { standardised volume of fluid (at least } 150 \mathrm{ml}) \text {. } \\
\text { ii) Water is allowed as desired except for one hour before and one hour } \\
\text { after drug administration }\end{array}$ \\
\hline Japan & $\begin{array}{l}\text {-similar to U.S.A. } \\
\text {-If bioavailability under fasting conditions is markedly low, or a high } \\
\text { incidence of severe adverse effects is indicated, drugs may be given } \\
\text { postprandial. For a postprandial dose, the meal should be eaten } \\
\text { within } 15 \text { minutes, and the drug administered according to the dosing } \\
\text { regimen or } 30 \text { minutes.(NIHS Japan, 2000) }\end{array}$ & -Similar to Europe \\
\hline Canada & $\begin{array}{l}\text { - Similar to Europe } \\
\text {-All meals should be standardized and repeated on each study day. } \\
\text { (HPB BA/BE, 2009) }\end{array}$ & $\begin{array}{l}\text { - Similar to Europe } \\
\text { - When comparing the performance of two orally disintegrating dosage } \\
\text { forms that are intended to be taken without water, the comparative } \\
\text { bioavailability study should be designed to challenge the formulation } \\
\text { under the most discriminatory conditions. For such dosage formulations, } \\
\text { water should not be administered from one hour prior to dosing, } \\
\text { concurrent with dosing and up to one hour post dosing. }\end{array}$ \\
\hline U.S.A. & $\begin{array}{l}\text { - No food should be allowed for at least } 4 \text { hours post-dose } \\
\text {-Subjects should start the recommended meal } 30 \text { minutes prior to } \\
\text { administration of the drug product. Study subjects should eat this } \\
\text { meal in } 30 \text { minutes or less; however, the drug product should be } \\
\text { administered } 30 \text { minutes after start of the meal. } \\
\text { - Standardized meals scheduled at the same time in each period of } \\
\text { the study } \\
\text { (US FDA BA/BE, 2003) }\end{array}$ & $\begin{array}{l}\text { i) Subjects should be administered the drug product with } 240 \mathrm{~mL} \text { (8 fluid } \\
\text { ounces) of water. } \\
\text { ii) Water is allowed as desired except for one hour before and one hour } \\
\text { after drug administration }\end{array}$ \\
\hline Saudi Arabia & $\begin{array}{l}\text {-Similar to Europe } \\
\text { - Standard meals for each study periods can be provided no less than } \\
4 \text { hours after drug administration }\end{array}$ & $\begin{array}{l}\text {-The drug product should be administered with } 180 \mathrm{ml} \text { of water } \\
\text { immediately } \\
\text { - Water can be allowed ad libitum after } 2 \text { hours. }\end{array}$ \\
\hline ASEAN & -As per Saudi Arabia & $\begin{array}{l}\text {-As per Europe } \\
\text {-Hot drink or juice may be provided after } 3 \text { hours of drug administration }\end{array}$ \\
\hline South Korea & Similar to U. S. & Similar to U. S. \\
\hline
\end{tabular}




\begin{tabular}{|l|l|}
\hline Mexico & $\begin{array}{l}\text { Volunteers' diet during the study should be homogeneous } \\
\text { and consistent with its own design(Guidance for medication } \\
\text { interchangeability, 1999). }\end{array}$ \\
\hline
\end{tabular}

Japan special requirement

-Subjects with low gastric acidity are required in cases where the average dissolution percent of a slower dissolution product is less than $50 \%$ at the time when the average dissolution of a faster dissolution product reaches $80 \%$ in water or neutral test solution. However, this rule is not applied to rapidly dissolving products when more than $85 \%$ of the drug dissolves from both products in water or neutral test solution.

-For basic drugs for which dissolution tests cannot be conducted using water or neutral solution because of low solubility, selection of subjects should be based on the results obtained at around $\mathrm{pH} 3-5$.

-If clearance of drugs largely differs among subjects due to genetic polymorphism, it is recommended that subjects with higher clearance be employed.

-If the use of drugs is limited to a special population, and dissolution profiles differ significantly between reference and test products, bioequivalence studies with subjects of the population may be needed.

\section{iii) Fasting requirement:}

\begin{tabular}{|l|l|}
\hline Regulatory Agency & Fasting \\
\cline { 1 - 1 } Europe & \multirow{3}{*}{ At least 8 hours prior to administration of the products and no food is allowed for at least 4 hours post-dose. } \\
\cline { 1 - 1 } Japan 10 hours of fasting which is continued for at least 4 hours post-dose. \\
\cline { 1 - 1 } Saudi Arabia & \multicolumn{1}{|l|}{$\begin{array}{l}\text { At least } 8 \text { hours prior to administration of the products. If the Summary of Product Characteristics of the reference product } \\
\text { contains specific recommendations in relation with food intake related to food interaction effects the study should be designed } \\
\text { accordingly }\end{array}$} \\
\hline A.S.A & $\begin{array}{l}\text { volunteers must be fasting for at least } 10 \text { hours before administering the medication and for at least two hours after } \\
\text { administration }\end{array}$ \\
\hline Mexico &
\end{tabular}

b) Fed study Requirement: As per US, Europe, TGA a high fat and a high caloric meal are recommended as test meal for Fed BE study. Fat should be $50 \%$ of total caloric content of the meal and 800 to 1000 calories considered as high calories. As per US, Europe, TGA regulation meal should contain 150 calories of protein, 250 calories of carbohydrates and 500-600 calories of fat. But In NIHS (Japanese, 2000) guidance the low fat and high caloric food is recommended. The caloric content is approximately $700 \mathrm{kcal}$ out of which not more than $20 \%$ (140 kcal) is derived from the fat.

c) Sample size: Number of subject will be selected depend up on the variability of drug and acceptance criteria of drug. The minimum number of subject for crossover design will be 12 but appropriate sample size will be determined based on previous available data or data available from pilot study. (BE Guideline of Saudi Arabia, 2005).

\begin{tabular}{|c|c|c|}
\hline Regulatory Agency & Minimum & Maximum \\
\hline $\begin{array}{l}\text { U.S.A and } \\
\text { South Korea }\end{array}$ & 12 & $\begin{array}{l}\text { The total number of subject in the study should } \\
\text { provide adequate power for BE demonstration. }\end{array}$ \\
\hline Europe & 12 & \multirow{4}{*}{$\begin{array}{l}\text {-Not Specified in BE Guideline } \\
\text {-ICH E9 section } 3.5 \text { applies which state ' The } \\
\text { number of subject in clinical trial should always } \\
\text { large enough to provide a reliable answer to the } \\
\text { question addressed }\end{array}$} \\
\hline WHO & 12 & \\
\hline Canada & 12 & \\
\hline Australia & 12 & \\
\hline ASEAN & 12 & \multirow{6}{*}{-Not Specified in BE Guideline } \\
\hline Malaysia & 12 & \\
\hline Argentina & 12 & \\
\hline Japan & 20 & \\
\hline Brazil & 24 & \\
\hline Saudi Arabia & 12-24 (I statistically justifiable) & \\
\hline New Zealand & 12 & $\begin{array}{l}\text { If the calculated number of subject to be higher } \\
\text { than is ethically justifiable, it may be necessary } \\
\text { to accept a statistical power which is less than } \\
\text { desirable. Normally it is not practical to use more } \\
\text { than about } 40 \text { subject in bioavailability study }\end{array}$ \\
\hline Mexico & $\begin{array}{l}\text { Sample size must not be smaller than } 24 \text { subjects considering both sequences or it } \\
\text { must meet the requirement related to a difference to be detected of } \pm 20 \% \text { regarding } \\
\text { the reference product's mean, associated with a type-l error }\left(^{*}\right) \text { of } 0.05 \text { and a minimal } \\
\text { potency of }\left(1-^{\star}\right) \text { of } 0.8 \text { for this kind of design. } \\
\text { A sample size smaller than } 24 \text { subjects must be scientifically justified. (Mexican Official } \\
\text { journal of Medication interchangeability (1999) section I: } 50 \text { ). }\end{array}$ & Not Specified in BE Guideline \\
\hline
\end{tabular}


Citation: Tamboli AM, Todkar P, Zope P, Sayyad FJ (2010) An Overview on Bioequivalence: Regulatory Consideration for Generic Drug Products. J Bioequiv Availab 2: 086-092. doi:10.4172/jbb.1000037

\section{Dropout and withdrawn}

As per U.S. Saudi Arabia, Asian, Mexico, South Africa regulatory recommend that Sponsors should enroll a sufficient number of subjects in the study with consideration for dropouts and withdrawn from study due to related adverse event or any other reasons. Because replacement of subjects could complicate the statistical model and analysis, dropouts generally should not be replaced.

\section{Add on design}

There might be chance that study sample size calculation does not give accepted result. Following countries provided Add on approach for such study along with there application.

\begin{tabular}{|c|c|}
\hline Regulatory Agency & Add on \\
\hline Europe \& Australia & $\begin{array}{l}\text { It is acceptable to use a two-stage approach when attempting to demonstrate bioequivalence. An initial group of subjects can be } \\
\text { treated and their data analysed. If bioequivalence has not been demonstrated an additional group can be recruited and the results } \\
\text { from both groups combined in a final analysis. If this approach is adopted appropriate steps must be taken to preserve the overall } \\
\text { type I error of the experiment and the stopping criteria should be clearly defined prior to the study. The analysis of the first stage } \\
\text { data should be treated as an interim analysis and both analyses conducted at adjusted significance levels. (Europe BA/BE CPMP/ } \\
\text { EWP/QWP/1401/98 Rev. } 1 / \text { Corr *). }\end{array}$ \\
\hline Japan & Also for add on study additional 10 subjects are recommended along with initial subjects \\
\hline Canada & $\begin{array}{l}\text { As a result of random variation or a larger than expected relative difference, there is no guarantee that the sample size as } \\
\text { calculated will pass the standards. If the study is run with the appropriate size and the standards are not met, the sponsor may add } \\
\text { more subjects (a minimum of 12). The same protocol should be used (i.e., same formulations, same lots, same blood sampling } \\
\text { times, a minimum number of } 12 \text { subjects, etc.). The choice to use this strategy, as with all designs, should be declared and justified } \\
\text { a priori. } \\
\text { The level of confidence should be adjusted using the Bonferroni procedure. The t-value should be that for } p=.025 \text { instead of } .05 \text {. } \\
\text { (HPB BA/BE Canada, 2009) }\end{array}$ \\
\hline South Africa & $\begin{array}{l}\text { If the bioequivalence study was performed with the appropriate size but bioequivalence cannot be demonstrated because of a } \\
\text { result of a larger than expected random variation or a relative difference, an add-on subject study can be performed using not less } \\
\text { than half the number of subjects in the initial study. Combining is acceptable only in the case when the same protocol was used } \\
\text { and preparations from the same batches were used. Add-on designs must be carried out strictly according to the study protocol } \\
\text { and SOPs, and must be given appropriate statistical treatment, including consideration of consumer risk.(MCC Guideline version } 3 \\
\text { Jun 2010). }\end{array}$ \\
\hline
\end{tabular}

d) Type of study: The number of studies and study design depend on the physico-chemical characteristics of the substance, its pharmacokinetic properties and proportionality in composition, and should be justified accordingly. Various regulatory provide detail regarding type of study required to be carried out shown below.

\begin{tabular}{|c|c|c|}
\hline Regulatory Agency & Immediate Release & Modified Release \\
\hline U.S.A & $\begin{array}{l}\text { Total of } 2 \text { studies: } \\
1 \text { single dose crossover study fasted } \\
1 \text { single dose crossover study, fed* } \\
\text { * If food mentioned in the product } \\
\text { Monograph if a multiple-dose study design is important, } \\
\text { appropriate dosage administration and sampling be carried } \\
\text { out to document attainment of steady state. }\end{array}$ & $\begin{array}{l}\text { Fasting and fed } \\
\text { If a multiple-dose study design is important, appropriate dosage } \\
\text { administration and sampling be carried out to document attainment of } \\
\text { steady state. }\end{array}$ \\
\hline Europe \& Australia & $\begin{array}{l}\text { Total of } 1-2 \text { studies: } \\
1 \text { single dose crossover study, } \\
\text { Fasted. } \\
\text { OR } \\
\text { Fed condition according to SmPC } \\
\text { Recommendations related with food interaction effects. } \\
\text { (Europe BA/BE CPMP/EWP/QWP/1401/98 Rev. 1/ Corr *). }\end{array}$ & Fasting, fed and steady state \\
\hline Japan & Fasting and fed & Fasting, fed and steady state \\
\hline Canada & Fasting & $\begin{array}{l}\text { Fasting and fed } \\
\text { If Steady-state studies are required, the food and fluid conditions and } \\
\text { restrictions noted above should apply on the preceding evening and on } \\
\text { the day the plasma profiles are to be obtained. .(HPB BA/BE Canada, } \\
\text { 2009). }\end{array}$ \\
\hline Saudi Arabia & $\begin{array}{l}\text { Fasting and if food effect from document evidence or drug } \\
\text { requires to be administered in fed condition in this case fed } \\
\text { study required. }\end{array}$ & Fasting and fed \\
\hline South Korea & Fasting & Fasting fed and steady state \\
\hline
\end{tabular}

e) Strength to be investigated: If several strengths of a test product are applied for, it may be sufficient to establish bioequivalence at only one or two strengths, depending on the proportionality in composition between the different strengths. The strength(s) to evaluate depends on the pharmacokinetics of the active substance. 


\begin{tabular}{|c|c|c|}
\hline Regulatory Agency & Linear Pharmacokinetics & Non Linear Pharmacokinetics \\
\hline U.S.A & $\begin{array}{l}\text { Reference Listed Drug (RLD) in the } \\
\text { Orange Book* } \\
\text { *usually the highest strength if } \\
\text { formulations are proportionally } \\
\text { similar }\end{array}$ & $\begin{array}{l}\text { Not addressed in Guidances. Refer to Reference Listed Drug (RLD) in the } \\
\text { Orange Book }\end{array}$ \\
\hline Europe \& Australia & $\begin{array}{l}\text { The bioequivalence study should in general be conducted at the } \\
\text { highest strength } \\
\text { Highly soluble drug and any safety concern: Lower strength } \\
\text { acceptable } \\
\text { Problems of sensitivity of the analytical method: Highest strength } \\
\text { acceptable }\end{array}$ & $\begin{array}{l}\text { * For drugs with non-linear pharmacokinetics characterized by a more than } \\
\text { proportional increase in AUC with increasing dose over the therapeutic } \\
\text { dose range, the bioequivalence study should in general be conducted at } \\
\text { the highest strength. As for drugs with linear pharmacokinetics a lower } \\
\text { strength may be justified if the highest strength cannot be administered to } \\
\text { healthy volunteers for safety/tolerability reasons. Likewise a higher dose } \\
\text { may be used in case of sensitivity problems of the analytical method in line } \\
\text { with the recommendations given for products with linear pharmacokinetics } \\
\text { above. } \\
{ }^{*} \text { For drugs with a less than proportional increase in AUC with increasing } \\
\text { dose over the therapeutic dose range, bioequivalence should in most cases } \\
\text { be established both at the highest strength and at the lowest strength (or } \\
\text { strength in the linear range), i.e. in this situation two bioequivalence studies } \\
\text { are needed. } \\
\text { If the non-linearity is not caused by limited solubility but is due to e.g. } \\
\text { saturation of uptake transporters and provided that a) same manufacturing } \\
\text { process b) Qualitative composition of the different strengths is the same c) } \\
\text { composition of the strengths are quantitatively proportional d) appropriate } \\
\text { in vitro dissolution data should confirm the adequacy of waiving additional } \\
\text { in vivo } \\
\text { Bioequivalence testing and the test and reference products do not contain } \\
\text { any excipients that may affect gastrointestinal motility or transport Protein, } \\
\text { it is sufficient to demonstrate bioequivalence sport proteins at the lowest } \\
\text { strength (or strength in the linear range). (Europe BA/BE CPMP/EWP/ } \\
\text { QWP/1401/98 Rev. } 1 / \text { Corr *). }\end{array}$ \\
\hline Canada & $\begin{array}{l}\text { Use strength with largest sensitivity to identify differences in } \\
\text { formulation }\end{array}$ & \\
\hline Saudi Arabia & $\begin{array}{l}\text { For conventional (immediate release) solid oral drug products, } \\
\text { in vivo bioequivalence studies are conducted on the highest } \\
\text { strength. This requirement for the lower strengths can be waived } \\
\text { provided: (a) in vivo bioequivalence is demonstrated on the highest } \\
\text { strengths; (b) in-vitro dissolution testing is acceptable; and (c) the } \\
\text { formulation for the lower strengths are proportionally similar to the } \\
\text { strength which has undergone in vivo bioequivalence testing (i.e., } \\
\text { the ratio of active ingredients and excipients between the strengths } \\
\text { is essentially the same). }\end{array}$ & Not addressed in Guidances \\
\hline
\end{tabular}

f) Parameter to be determined: For single dose study pharmacokinetic parameter $C_{\text {max }}, A C_{0-t}, A_{0} C_{0-\infty}$ residual area $T_{\text {max }}$, Kel, $t_{1 / 2}$ is determined using plasma time concentration profile of drug For multiple dose studies $\mathrm{AUC}_{(0-\tau),} \mathrm{C}_{\max , \mathrm{ss}}$ and $\mathrm{t}_{\text {max.ss }}$ determined using plasma time concentration profile of drug. (FDA BA/BE General consideration 2003).

g) Statistical analysis: Statistical analysis will be performed on the data obtained from subjects. Descriptive statistics of all the pharmacokinetic parameters will be computed and reported. (FDA BA/BE Statistical approach 2001; Rani and Pargal, 2004).

Analysis of variance (ANOVA): The In-transformed pharmacokinetic parameters $C_{\max }, \mathrm{AUC}_{0-\mathrm{t}}$ and $\mathrm{AUC}_{0-\infty}$ of analyte will be subjected to Analysis of Variance (ANOVA). ANOVA model will include Sequence, Formulation and Period as fixed effects and Subject (Sequence) as a random effect. Sequence effect will be tested using Subject (Sequence) as error term. The significance of the sequence effect at alpha 0.10 will be tested using the subjects nested within the sequence as the error term. An F-test will be performed to determine the statistical significance of the effects involved in the model at a significance level of $5 \%$ (alpha $=0.05$ ).

Power: The power of a test to detect $20 \%$ difference between test and reference formulations will be computed and reported.

Ratio analysis: Ratio of least squares means of test and reference formulations will be computed for In-transformed pharmacokinetic parameters $\mathrm{C}_{\text {max }}, \mathrm{AUC}_{0-\mathrm{t}}$ and $\mathrm{AUC}_{0-\infty}$.

Ratio analysis will be reported for In-transformed pharmacokinetic parameters $C_{\max }, \mathrm{AUC}_{0-\mathrm{t}}$ and $\mathrm{AUC}_{0-\infty}$ for analyte.

Intra-subject variability: Intra-Subject variability will be computed for In-transformed pharmacokinetic parameters $C_{\max }, A C_{0-t}$ and $A U C_{0-\infty}$ for analyte.

Acceptance parameter for bioequivalence: Two one-sided test for bioequivalence and $90 \%$ confidence intervals for the ratio of least squares mean between drug formulations will be calculated, for In-transformed data of $C_{\text {max, }} A_{-1} C_{0-t}$ and $A C_{0-\infty}$ for single dose study and AUC $C_{(0-\tau)}$ and $\mathrm{C}_{\text {max,ss }}$ for multiple dose study.

In Europe and South Korea guideline suggest that if the drug having long half life and sampling duration is more than 72 hours. In this case AUC is truncated upto $72 \mathrm{hr}$ and no need to measures $\mathrm{AUC}_{0-\infty}$ and residual area. 
Citation: Tamboli AM, Todkar P, Zope P, Sayyad FJ (2010) An Overview on Bioequivalence: Regulatory Consideration for Generic Drug Products. J Bioequiv Availab 2: 086-092. doi:10.4172/jbb.1000037

h) Acceptance criteria for bioequivalence:

\begin{tabular}{|c|c|c|c|}
\hline \multirow[t]{2}{*}{ Regulatory Agency } & \multicolumn{3}{|c|}{$90 \%$ confidence interval on Log transformed data } \\
\hline & $\mathbf{C}_{\max } \%$ & AUC $_{0-\mathrm{t}} \%$ & AUC $_{0-\infty} \%$ \\
\hline U.SA. & $80-125$ & $80-125$ & $80-125$ \\
\hline Europe \& Australia & $80-125$ & $80-125$ & Not Applicable \\
\hline Canada & $\begin{array}{l}\text { Ratio must be between } 80-125 \\
\text { Need to pass also on potency } \\
\text { corrected data. } \\
\text { Add-on studies may be allowed if } \\
\text { intra- CV greater than expected }\end{array}$ & $80-125$ & Not Applicable \\
\hline South Africa & $75-133$ & $80-125$ & Not Applicable \\
\hline Saudi Arabia & $80-125$ & $80-125$ & $80-125$ \\
\hline ASEAN & $80-125$ & $80-125$ & $80-125$ \\
\hline South Korea & $80-125$ & $80-125$ & $80-125$ \\
\hline Mexico & $80-125$ & $80-125$ & Not Applicable \\
\hline
\end{tabular}

Japan:

Products are considered to be bioequivalent, if the $90 \%$ confidence interval of difference in the average values of logarithmic AUC and Cmax between test and reference products is within the acceptable range of $\log (0.8)-\log (1.25)$. However, even though the confidence interval is not in the above range, test products are accepted as bioequivalent, if the following three conditions are satisfied (NIHS Japan, 2000).

1) The total sample size of the initial bioequivalence study is not less than 20 ( $n=10 /$ group) or pooled sample size of the initial and add-on subject studies is not less than 30 ,

2) The differences in average values of logarithmic $A U C$ and $C_{\text {max }}$ between two products are between log $(0.9)$ - $\log (1.11)$

3 ) Dissolution rates of test and reference products are evaluated to be equivalent as per dissolution test. The dissolution characteristics of the test product must be similar to those of the reference product under all of the following conditions when dissolution tests are performed according to the dissolution tests for oral conventional dosage forms and enteric coated products. Either the rotating basket or disintegration testing apparatus can be selected, the reason for which should be stated. The testing times are $2 \mathrm{hr}$ in pH 1.2 medium and $24 \mathrm{hr}$ in other test fluids. The test can be ended at the time when the average dissolution of reference product reaches $85 \%$. However, the $3 \mathrm{rd}$ rule can not be applied to slowly dissolving products from which more than $80 \%$ of a drug does not dissolve within the final testing time $(2 \mathrm{hr}$ in $\mathrm{pH} 1.2$ medium and $6 \mathrm{hr}$ in others) under any conditions of the dissolution tests described in Sec.3 A.V. of Japan guideline.

South Korea:

If the values are not between $\log 0.8-\log 1.25$, then the test drug product is considered BE, if all the following are met: (Korea FDA Notification \#2008-22 May 07, 2008)

1. In case the difference between the log-transformed mean values of comparative parameters of the test and reference drug products is within log $0.9-$ log 1.11 ;

2. In case the results of the dissolution test between the test and reference drug products are equivalent under all test conditions, according to the Regulation for the Management of the therapeutic Equivalence Test (KFDA Notification), although this provision is not applicable to solid oral preparations (except for controlled-release preparations) and enteric coated preparations, unless the average dissolution rate from the reference drug product reaches $85 \%$ within the specified time point (For controlled-release preparations, the average dissolution rate from the test drug product reaches within $\pm 10 \%$ of the average dissolution from the reference drug product at the time point at which the reference drug product dissolves at around 30,50 , and $80 \%$ ); and

3. The total number of subjects should be more than 24 (12 per group).

Acceptance Criteria for bioequivalence for special class drug:

\begin{tabular}{|c|c|c|c|c|}
\hline \multirow[t]{2}{*}{ Regulatory Agency } & \multicolumn{2}{|c|}{$\begin{array}{l}\text { Narrow therapeutic index drugs } \\
90 \% \text { confidence interval } \\
\text { Log transformed data }\end{array}$} & \multicolumn{2}{|l|}{$\begin{array}{l}\text { Highly variable drugs } \\
90 \% \text { confidence interval } \\
\text { Log transformed data }\end{array}$} \\
\hline & $\mathrm{C}_{\max }$ & $A \cup C_{0-t}$ & $\mathrm{C}_{\max }$ & $A \cup C$ \\
\hline U.S.A & $80-125$ & $80-125$ & $\begin{array}{l}\text { GMR }(80-125) 95 \% \text { upper bound } \\
\text { for }(\mu T-\mu R) / 62 W R \leq 0.7976 \\
\text { (Using Scaled Average Approach) }\end{array}$ & $\begin{array}{l}\text { GMR }(80-125) 95 \% \text { upper bound for } \\
(\mu T-\mu R) / \sigma 2 W R \leq 0.7976 \\
\text { (Using Scaled Average Approach) }\end{array}$ \\
\hline Europe & \multirow{2}{*}{$90.00-111.11$} & \multirow{2}{*}{$90.00-111.11$} & \multirow{2}{*}{\multicolumn{2}{|c|}{----- }} \\
\hline Japan & & & & \\
\hline Canada & & & GMR (80 -125) & $\begin{array}{l}\text { GMR }(80-125) \\
90 \% \mathrm{Cl}(80-125)\end{array}$ \\
\hline Saudi Arabia & $90-111$ & ---- & $75-133$ & $\begin{array}{l}\text { wider acceptance range may be } \\
\text { acceptable and this should be justified } \\
\text { clinically }\end{array}$ \\
\hline ASEAN & $\begin{array}{l}\text { acceptance interval may } \\
\text { need to be tightened }\end{array}$ & $\begin{array}{l}\text { acceptance interval may } \\
\text { need to be tightened }\end{array}$ & $\begin{array}{l}\text { The interval must be prospectively } \\
\text { defined e.g. } 0.75-1.33 \text { and justified } \\
\text { addressing in particular any safety } \\
\text { or efficacy concerns for patients } \\
\text { switched between formulation }\end{array}$ & $\begin{array}{l}\text { In rare cases a wider acceptance range } \\
\text { may be acceptable if it is based on } \\
\text { sound clinical }\end{array}$ \\
\hline
\end{tabular}

Europe guideline for highly variable drug: Highly variable drug products (HVDP) are those whose intra-subject variability for a parameter is larger than $30 \%$ (Europe BA/BE CPMP/EWP/QWP/1401/98 Rev. 1/ Corr *). If an applicant suspects that a drug product can be considered as highly variable in its rate and/or extent of absorption, a replicate cross-over design study can be carried out. Those HVDP for which a wider difference in $\mathrm{C}_{\max }$ is considered clinically irrelevant based on a sound clinical justification can be assessed with a widened acceptance range. If this is the case the acceptance criteria for $C_{\max }$ can be widened to a maximum of $69.84-143.19 \%$. For the acceptance interval to be widened the bioequivalence study must be of a replicate design where it has been demonstrated that the within-subject variability for Cmax of the reference 
compound in the study is $>30 \%$. The applicant should justify that the calculated intra-subject variability is a reliable estimate and that it is not the result of outliers. The request for widened interval must be prospectively specified in the protocol.

The extent of the widening is defined based upon the within-subject variability seen in the bioequivalence study using scaled-averagebioequivalence according to $[\mathrm{U}, \mathrm{L}]=\exp [ \pm \mathrm{k} \cdot \mathrm{sWR}]$, where $\mathrm{U}$ is the upper limit of the acceptance range, $\mathrm{L}$ is the lower limit of the acceptance range, $\mathrm{k}$ is the regulatory constant set to 0.760 and sWR is the within-subject standard deviation of the log-transformed values of Cmax of the reference product. The table below gives examples of how different levels of variability lead to different acceptance limits using this methodology.

\begin{tabular}{|c|c|c|}
\hline Within-subject CV $(\%)^{*}$ & Lower Limit & Upper Limit \\
\hline 30 & 125.00 & 77.00 \\
\hline 35 & 74.62 & 123 \\
\hline 40 & 72.15 & 134.02 \\
\hline 45 & 69.84 & 138.59 \\
\hline
\end{tabular}

The geometric mean ratio (GMR) should lie within the conventional acceptance range $80.00-125.00 \%$. The possibility to widen the acceptance criteria based on high intra-subject variability does not apply to AUC where the acceptance range should remain at $80.00-125.00 \%$ regardless of variability. It is acceptable to apply either a 3-period or a 4-period crossover scheme in the replicate design study.

\section{Conclusion}

Today, various pharmaceutical companies developing generic drug products. Bioequivalence study is important for generic drug approval process. It is our hope that, this review will provide an easy quick overview for Regulatory consideration required for bioequivalence study in different countries. This review covers major aspect of requirement of bioequivalence study along with the regulatory specification of various countries.

\section{References}

1. Canadian Health Protection Branch (HPB) (2009) Guideline on Conduct and Analysis of Comparative Bioavailability Studies.

2. Chinese Pharmacopoeia (2000) Edition 2. Drug bioavailability and bioequivalence testing guidance Principle, Appendix 193-197.

3. CPMP Guideline of TGA On the investigation of bioavailability and bioequivalence - CPMP/EWP/QWP/1401/98.

4. Diletti E, Hauschke D, Steinijans VW (1991) Sample size determination for bioequivalence assessment by means of confidence intervals. Int J Clin Pharmacol Ther Toxicol, 29:1-8.

5. European Medicines Agency- Doc Ref: EMEA/CHMP/EWP/200943/2007.

6. European Medicines Agency- Doc Ref: EMEA/CHMP/EWP/40326/2006

7. Guidance document for Bioequivalence study of Korea Food \& Drug Administration Notification \#2008-22 (May 07, 2008).

8. Guidance for Industry, Bioavailability and Bioequivalence Studies for Orally Administered Drug Products - General Considerations, U.S. department of health and human services, food and drug administration, center for drug evaluation and research (CDER), March 2003, BP

9. Guidance for Industry, food effect/fed BE studies, U.S. department of health and human services, food and drug administration, center for drug evaluation and research, Dec-2002, BP.

10. Guidance for medication interchangeability of Mexican Official journal (1999) section I: 45-68.

11. Guideline for Bioequivalence Studies of Generic Products (2000) National Institute of Health Sciences, Japan NIHS.

12. Guideline of Medicine control council on registration of medicine, version 3 Jun 2010

13. Interchangeable multi-source pharmaceutical products. WHO draft guideline on marketing authorization requirements, December 1993.

14. MHW Guideline for bioequivalence studies of generics products, Dec 1997.

15. Rani S, Pargal A (2004) Bioequivalence: An overview of statistical concepts. Indian J Pharmacol 36: 209-216.

16. Saudi Food and Drug Administration drug authority sector Bioequivalence Requirement guidelines, (2005)

17. Schuirmann DJ (1987) A comparison of the two one-sided test procedures and the power approach for assessing the equivalence of average bioavailability. $J$ Pharmacokinet Biopharm 15: 657-680.

18. Statistical Approaches to Establishing Bioequivalence US Food and drug administration center for evaluation of drug and research FDA, (2001).

19. The European Agency for the Evaluation of Medicinal Products - CPMP/EWP/QWP/1401/98 Rev. 1/ Corr *. 